\title{
Growth analysis of potato genotypes
}

\author{
Giovani Olegario da Silva ${ }^{1 *}$ (10), Fernanda Quintanilha Azevedo ${ }^{2}$, Carlos Francisco Ragassi ${ }^{3}$, \\ Agnaldo Donizete Ferreira de Carvalho ${ }^{3}$, Gabriel Emiliano Pereira ${ }^{4}$, Arione da Silva Pereira ${ }^{2}$
}

10.1590/0034-737X202067030006

\begin{abstract}
Analyzes of plant growth throughout the crop vegetative cycle are important to know the dynamics of the plant development. Thus the objective of this work was to study the development of potato genotypes throughout the crop cycle, in three environments. Experiments were conducted in Canoinhas-SC, Pelotas-RS, and Brasília-DF, Brazil, in the 2018 crop season. A randomized complete block experimental design with three replicates was used. Traits related to different plant parts of clones F183-08-01 and F50-08-01 and the cv. Asterix were evaluated as a function of time and, at the end of the cycle, for tuber yield. The two clones were found to have high tuber yields, but later development than 'Asterix'; consequently, its management must be adapted to this trait. Leaf mass, leaf number, leaf area index and root mass plus stems were correlated with each other, and leaf area index, leaf number and leaf mass can be quantified through only one of these traits, due to the high correlation between them. There were also positive and significant correlations between the height of the tallest stem and the root plus stem mass and the tuber mass, indicating that more vigorous plants have higher tuber yield.
\end{abstract}

Keywords: Solanum tuberosum L.; growth curve; leaf area index; productivity.

\section{INTRODUCTION}

About 3.65 million tons of potatoes are produced each year in Brazil, in an area of approximately 118 thousand hectares, with an average yield of $31.0 \mathrm{tha}^{-1}$ (IBGE, 2018).

The potato is of Andean origin, and the most cultivated species in the world, Solanum tuberosum ssp. tuberosum, was selected and adapted to European cultivation conditions and subsequently disseminated throughout the world, including Brazil. Therefore, it is better adapted to long photoperiods and, when cultivated under shorter daylength, as occurs in the main producing regions of Brazil, it presents a very short growing cycle, requiring a large amount of fertilizers to reach high yields (Silva et al., 2018a).

In addition, climate, soil and disease conditions found in the country's main potato producing regions are quite different from those prevailing in temperate regions (Silva et al., 2012; Moreira et al., 2015; Silva et al., 2018a). Thus, the development and evaluation of cultivars more adapted to the Brazilian growing conditions are fundamental for the potato chain.

Plant development depends on genotype-environment interaction for trait expression. Based on the analysis of plant growth, it is possible to evaluate yield potential of genotypes and also to know plant development over time, including under the soil (Escalante et al., 2016).

This information is important to determine the best stages for performing cultural treatments, such as the planting density to be used, heaping, fertilizer timing and dose application of top dressing, phytosanitary control, and plant topkilling.

In addition to knowledge about the rate of tuber formation and development, it is important to know the

\footnotetext{
Submitted on November $21^{s t}, 2019$ and accepted on April $28^{\text {th }}, 2020$.

${ }^{1}$ Embrapa Hortaliças, Canoinhas Experimental Station, Canoinhas, Santa Catarina, Brazil. giovani.olegario@embrapa.br

Embrapa Clima Temperado, Pelotas, Rio Grande do Sul, Brazil. fernanda.azevedo@embrapa.br; arione.pereira@embrapa.br

3Embrapa Hortaliças, Gama, Distrito Federal, Brazil. carlos.ragassi@embrapa.br; agnaldo.carvalho@embrapa.br

${ }^{4}$ Universidade de Brasília, Brasília, Distrito Federal, Brazil. gb.emiliano28@gmail.com

*Corresponding author: giovani.olegario@embrapa.br
} 
dynamics of leaf and stem formation and maintenance, responsible for photoassimilate production processes; because approximately $90 \%$ of plant mass results from photosynthetic activity, and 10\% from absorption and accumulation of soil nutrients. Photoassimilates are first accumulated in the leaves and stems, and later translocated to the tubers after the start of tuberization, which occurs about 30 days after planting (Fernandes et al., 2010).

There are several ways to evaluate plant and development and determining leaf area development is one of the most important and efficient. Leaf area is an important trait in the evaluation of plant photosynthetic capacity, and may be influenced by the occurrence of biotic and abiotic damage, plant metabolism, and influence on final yield, quality and crop maturity (Busato et al., 2010; Virmond et al., 2017). The leaf area index expresses the ratio between the existing leaf area in the plant and the soil area occupied by it and describes the size of the crop assimilator system. Higher leaf area indices indicate larger leaf area for solar radiation interception and, within certain limits, higher indices are associated with higher plant growth and higher tuber yield (Jadoski et al., 2012).

Plant development can be affected by a number of variables, including climate, soil and crop conditions. Therefore, to characterize the superiority of genotypes, it is important to consider their responses to the different environments of growing regions.

The objective of this work was to study the development of potato genotypes throughout the crop cycle in three environments.

\section{MATERIAL AND METHODS}

Three experiments were conducted to analyze the growth and development of advanced potato clones F18308-01 and F50-08-01 from the Brazilian Agricultural Research Corporation (Embrapa) breeding program, compared to the cultivar Asterix, which is widely grown for fresh market and French fry processing in Brazil.

The experiments were carried out in Canoinhas-SC (26¹0'38" S, 50²3'24" W, $765 \mathrm{~m}$ a.s.l.) and Pelotas-RS (31 $52^{\prime} 00^{\prime \prime} \mathrm{S}, 52^{\circ} 25^{\prime} 00^{\prime \prime} \mathrm{W}, 50 \mathrm{~m}$ a.s.l.) in the spring crop season of 2018, and in Brasilia-DF (15 $55^{\circ}$ '44" S, 48 08'29" W, 999 m a.s.l.) in the winter season of 2018. In Brasilia, the clone F50-08-01 was not evaluated. Planting dates were 06/08/2018,08/16/2018 and 15/05/2018, respectively.

Type II seeds (diameter $40-50 \mathrm{~mm}$ ) stored for six months in cold stored $\left(3.5 \pm 0.5^{\circ} \mathrm{C}\right)$ were used. Fertilizers were applied in the furrow. In Canoinhas, $3,000 \mathrm{~kg} \mathrm{ha}^{-1}$ of the formulated NPK 04-14-08 was used; in Pelotas, $3,500 \mathrm{~kg}$ $\mathrm{ha}^{-1}$ of NPK 05-20-10; and in Brasilia, 3,000 kg ha' ${ }^{-1}$ of NPK 04-30-16 + 0.5\% Zn. Earthing up was done about 40 days after planting (DAP) in Pelotas and Canoinhas, and 25
DAP in Brasilia. Crop and phytosanitary practices followed recommendations of the respective regions.

The randomized complete block design with three replications was used. The useful plot consisted of two rows of 25 plants each, spaced $0.75 \mathrm{~m}$ between rows and $0.30 \mathrm{~m}$ between plants. An external guard row was used in each plot.

Plants were harvested at 30, 44, 58, 72, 82 and 100 DAP in Canoinhas; at 34, 48, 62, 76, 90 and 105 DAP in Pelotas; and at 38, 52, 66 and 80 DAP in Brasilia. One external plant per row of the useful plot was discarded before each harvest, and four plants were harvested in each plot (two per useful row), evaluated together, and the average values of the four plants in each harvest were obtained.

The following traits were evaluated: fresh mass of compound leaves, g (leaf mass); fresh root mass plus stems, g (root mass + stem); total tuber number (tuber number); tuber mass, g (tuber mass); number of stems (number of stems); height of the largest stem of each plant, cm (height of > stem). Leaf area index (LAI) was also evaluated, obtained by the ratio between the leaf area and the area occupied by the plants $\left(\mathrm{m}^{2} / \mathrm{m}^{2}\right)$. To calculate the plant leaf area, the leaf disc method was used, by collecting 20 leaf discs with the aid of a perforator with a known area, weighing the leaf discs on a precision scale and extrapolating these values in relation to the mass of the leaves (leaf mass), according to the methodology adapted from Lima et al. (2007).

At the time of the last harvest held in Canoinhas and Pelotas, 100 DAP, and in Brasilia, 105 DAP, the tuber yield was evaluated using the remaining 16 plants per plot: total tuber yield, t ha-1 (TTY); marketable tuber yield (transverse diameter $>45 \mathrm{~mm}$ ), $\mathrm{t} \mathrm{ha}^{-1}$; marketable tuber number, $\mathrm{ha}^{-1} /$ 1000; average marketable tuber mass, g; and percentage of marketable tubers mass (\% marketable tubers).

Variance, regression and correlation analyzes were performed on data of traits evaluated during the vegetative cycle of the plants, and Scott-Knott grouping of means ( $p$ d" 0.05 ) on data of yield traits evaluated at the end of the cycle, using the Genes software (Cruz, 2013).

\section{RESULTS AND DISCUSSION}

Significant differences among genotypes for most traits evaluated during the crop cycle were found in Canoinhas and Pelotas experiments, and for all traits evaluated in Brasília (Tables 1, 2, 3 and 4). Differences among genotypes and genotype-environment interactions by date of harvest were not significant for tuber mass, stem number and height of the tallest stem of each plant for Canoinhas and Pelotas (Tables 1 and 2). Therefore, for these traits a single regression equation was adjusted considering the mean value of the three genotypes. 
Table 1: Regression equations for plant traits evaluated between 30 and 100 days after planting of three potato genotypes in Canoinhas-SC, in the spring crop season of 2018

\begin{tabular}{|c|c|c|c|}
\hline Leaf mass(g) & Root mass + Stem mass(g) & $\mathbf{L A I}\left(\mathbf{m}^{2} / \mathbf{m}^{2}\right)$ & Leaf number \\
\hline \multicolumn{4}{|c|}{ Asterix } \\
\hline$y=0.0127 x^{3}-3.5203 x^{2}+282.24 x-5616.9$ & $y=-0.9143 x^{2}+119.78 x-2623.5$ & $y=0.00002 x^{3}-0.0047 x^{2}+0.3816 x-8.11$ & $y=-0.1938 x^{2}+24.112 x-443.75$ \\
\hline $\mathrm{R}^{2}=0.80 \mathrm{P}=0.05$ & $\mathrm{R}^{2}=0.98 \mathrm{P}=<0.01$ & $\mathrm{R}^{2}=0.80 \mathrm{P}=0.05$ & $\mathrm{R}^{2}=0.88 \mathrm{P}=0.05$ \\
\hline MP: $347.36 \mathrm{~g}$ at 58.79 days & MP: $324.88 \mathrm{~g}$ at 65.50 days & MP: 2.55 at 78.33 days & MP: 76.56 at 62.20 days \\
\hline \multicolumn{4}{|c|}{ F50-08-01 } \\
\hline$y=-1.1294 x^{2}+155.79 x-3576.6$ & $y=-0.8884 x^{2}+145.35 x-466$ & $y=-0.0012 x^{2}+0.1676 x-3.6442$ & $y=-0.1771 x^{2}+24.336 x-467.85$ \\
\hline $\mathrm{R}^{2}=0.87 \mathrm{P}=<0.01$ & $\mathrm{R}^{2}=0.99 \mathrm{P}=<0.01$ & $\mathrm{R}^{2}=0.87 \mathrm{P}=0.03$ & $\mathrm{R}^{2}=0.94 \mathrm{P}=0.05$ \\
\hline MP: 448.96 at 68.97 days & MP: 619.78 at 81.80 days & MP: 2.20 at 69.83 days & MP: 92.04 at 68.70 days \\
\hline \multicolumn{4}{|c|}{ F183-08-01 } \\
\hline$y=0.0192 x^{3}-4.8458 x^{2}+365.71 x-7207.7$ & $y=-0.8029 x^{2}+122.42 x-2968.6$ & $y=0.00003 x^{3}-0.0063 x^{2}+0.4755 x-10.3557$ & $y=-0.2103 x^{2}+26.926 x-534.3$ \\
\hline $\mathrm{R}^{2}=0.80 \mathrm{P}=0.05$ & $\mathrm{R}^{2}=0.94 \mathrm{P}=<0.01$ & $\mathrm{R}^{2}=0.81 \mathrm{P}=0.05$ & $\mathrm{R}^{2}=0.81 \mathrm{P}=0.05$ \\
\hline MP: 362.37 at 57.14 days & MP: 424.46 at 76.24 days & MP: 2.34 at 70 days & MP: 81.89 at 64.02 days \\
\hline Overall mean: 216.19 & Overall mean: 302.83 & Overall mean: 1.05 & Overall mean: 55.47 \\
\hline CV: 22.98 & CV: 20.77 & CV: 22.87 & CV: 13.87 \\
\hline $\mathrm{CVg} / \mathrm{CV}: 3.28$ & $\mathrm{CVg} / \mathrm{CV}: 2.50$ & $\mathrm{CVg} / \mathrm{CV}: 3.37$ & $\mathrm{CVg} / \mathrm{CV}: 3.50$ \\
\hline \multicolumn{4}{|c|}{ Mean of the three genotypes } \\
\hline Tuber mass. g & Stem number & Height of > stem. cm & - \\
\hline$y=48.819 x-1849.2$ & $y=-0.005 x^{2}+0.4738 x+22.428$ & $y=-0.0186 x^{2}+3.5143 x-75.63$ & \\
\hline $\mathrm{R}^{2}=0.96 \mathrm{P}=0.02$ & $\mathrm{R}^{2}=0.92 \mathrm{P}=0.05$ & $\mathrm{R}^{2}=0.99 \mathrm{P}=0.05$ & \\
\hline MP: 758.17 at 100 days & MP: 8.41 at 47.38 days & MP: 90.00 at 94.47 days & - \\
\hline Overall mean: 331.01 & Overall mean: 7.33 & Overall mean: 15.62 & - \\
\hline CV: 30.00 & CV: 22.45 & CV: 9.64 & \\
\hline $\mathrm{CVg} / \mathrm{CV}: 3.26$ & $\mathrm{CVg} / \mathrm{CV}: 0.76$ & $\mathrm{CVg} / \mathrm{CV}: 5.06$ & \\
\hline
\end{tabular}

Leaf mass (mass of compound leaves detached from stems of each plant), g; Root mass + stem mass (mass of roots plus mass of stems of each plant), g; IAF (foliar area index, obtained by the rate between the measurements of square footage area occupied by the leaves of each plant, by the plot area occupied by the plants), $\mathrm{m}^{2} / \mathrm{m}^{2}$; Leaf number (total number of leaves of each plant); Tuber mass (mass of tubers of each plant), g; Stem number (number of stems of each plant); Height > stem (height of the highest plant), $\mathrm{cm}^{2} \mathrm{R}^{2}$ : regression determination coefficient; P: P-statistic of the analysis of variance to the highest significant degree of the regression coefficients; MP: maximum production obtained and correspondent period; CV: coefficient of variation; CVg/CV: rate between the genotypic and phenotypic coefficient of variation. 
Table 2: Regression equations for plant traits evaluated between 34 and 105 days after planting of three potato genotypes in Pelotas-RS, in the spring crop season of 2018

$y=-0.0707 x^{2}+10.663 x-273.51$

$\mathrm{R}^{2}=0.92 \mathrm{P}=0.05$

MP: 128.53 at 75.41 days

\section{Leaf mass. $\mathrm{g}$}

$y=-0.1106 x^{2}+18.086 x-491.41$

$\mathrm{R}^{2}=0.89 \mathrm{P}=0.05$

MP: 247.97 at 81.76 days

\section{Leaf mass. $\mathrm{g}$}

$y=-0.0684 x^{2}+12.274 x-345.47$

$\mathrm{R}^{2}=0.90 \mathrm{P}=0.05$

MP: 205.15 at 89.72 days

Overall mean: 129.00

CV: 23.23

CVg/CV: 2.51

Tuber mass. $\mathbf{g}$

\begin{abstract}
$y=-0.0002 x^{3}+0.016 x^{2}+0.8914$
$R^{2}=0.80 P=0.05$
\end{abstract}
MP: 50.60 at 73.54 days

$-21.945 \mathrm{y}=-0.0003$

ens

$y=-0.0059 x^{3}+1.2092 x^{2}-70.361 x+1228.9 \quad y=0.00002 x^{3}-0.0045 x^{2}+0.2878 x-1.5433$

$\mathrm{R}^{2}=0.99 \mathrm{P}=<0.01$

$\mathrm{R}^{2}=0.91 \mathrm{P}=0.04$

MP: 399.19 at 94.58 days

MP: 4.12 at 46.22 days

Overall mean: 201.72

Overall mean: 3.58

CV: 27.64

CV: 32.38

CVg/CV: 0.32

Leaf mass (mass of compound leaves detached from stems of each plant), g; Root mass + stem mass (mass of roots plus mass of stems of each plant), g; IAF (foliar area index, obtained by the rate between
the measurements of square footage area occupied by the leaves of each plant, by the plot area occupied by the plants), $\mathrm{m}^{2} / \mathrm{m}^{2} ;$ Leaf number (total number of leaves of each plant); Tuber mass (mass of tubers of each plant), g; Stem number (number of stems of each plant); Height >stem (height of the highest plant), $\mathrm{cm}$. $\mathrm{R}^{2}$ : regression determination coefficient; MP: maximum production obtained and correspondent period; $\mathrm{CV}$ : coefficient of variation; $\mathrm{CVg} / \mathrm{CV}$ : rate between the genotypic and phenotypic coefficient of variation.
$8 x-1.1752 y=0.0002 x^{3}-0.062 x^{2}+5.1025 x-88.513$

$\mathrm{R}^{2}=0.88 \mathrm{P}=0.05$

$\mathrm{R}^{2}=0.68 \mathrm{P}=0.05$

MP: 0.49 at 74.66 days

MP: 42.40 at 105 days

LAI. $\mathrm{m}^{2} / \mathrm{m}^{2} \quad$ Leaf number

LAI. $\mathbf{m}^{2} / \mathbf{m}^{2}$

$y=-0.0134 x^{2}+2.5024 x-51.665$

$\mathrm{R}^{2}=0.97 \mathrm{P}=0.05$

MP: 0.63 at 76.37 days

MP: 65.16 at 93.37 days

F183-08-01

\section{Leaf number}




\section{Canoinhas experiment}

In Canoinhas, quadratic or cubic responses were verified for most traits (Table 1). Exception for the tuber mass, which presented linear growth up to 100 DAP. Phenotypic coefficients of variation were lower for leaf number (CV: $13.87 \%)$ and higher for the tuber mass (CV: $30 \%)$. However, the ratio between the genotypic and phenotypic coefficients of variation $(\mathrm{CVg} / \mathrm{CV})$ was higher than the unit for most traits, indicating a predominance of genetic effects and reliability in the results (Cruz et al., 2014), except for the stem number, for which the ratio was 0.76.

The fresh mass of composite leaves peaked near 60 DAP for cultivar Asterix and clone F183-08-01 (58.79 and 57.14 DAP, respectively), with similar mass (347.36 and $362.37 \mathrm{~g} \mathrm{plant}^{-1}$, respectively). The clone F50-08-01 presented higher fresh mass of composite leaves (448.06 g) than the other two genotypes; however, the maximum value occurred later, at 68.97 DAP (Table 1).

Root fresh mass plus stems mass showed lower values for 'Asterix', intermediate for F183-08-01 and higher for F50-08-01. The leaf number also presented the same response pattern for the three genotypes, with the highest maximum value for F50-08-01 at 68.70 DAP, a period similar to the maximum leaf mass (68.97 DAP). The leaf area index showed maximum values ranging from 2.20 to 2.55 , i.e., leaf surface equivalent to slightly more than double the area occupied by plants (Table 1 ).

Tuber mass increased until the last harvest, at 100 DAP (758.17 $\left.\mathrm{g} \mathrm{plant}^{-1}\right)$. The maximum stem number was reached earlier than the other traits, at $47.38 \mathrm{DAP}$, with an average of 8.41 stems plant $^{-1}$. The length of the tallest stem of each plant, however, continued to grow up to near $95 \mathrm{DAP}$, with a maximum value of $90 \mathrm{~cm}$ on the average of the three genotypes (Table 1).

\section{Pelotas experiment}

In Pelotas, quadratic or cubic responses were verified for the traits, indicating that the evaluation period was sufficient to determine the point of maximum growth of the evaluated traits. Phenotypic coefficients of variation ranged from $10.80 \%$ for the height of the tallest stem, to values just over $30 \%$ for leaf number and stem number. For stem number, the rate between the genotypic and phenotypic coefficient of variation was low (CVg/CV: 0.32), showing a predominance of phenotypic variation over genotypic variation, as for Canoinhas, indicating that caution is needed regarding conclusions related to this trait. However, the ratio was higher than the unit for all other evaluated traits (Table 2).

The maximum values of leaf mass, root mass plus stem mass, leaf area index and leaf number were observed later than for Canoinhas, although the values were lower. This indicates that the plants grew less, although they continued to grow for a longer period of time. 'Asterix' presented the lowest values for these traits, F183-08-01 the highest, and F50-08-01 intermediate values. Tuber mass was maximum at 94.58 DAP; the height of the tallest stem was higher at 86.32 DAP; and stem number, as in Canoinhas, was earlier defined in comparison with the other traits, at 46.22 DAP, with a maximum value of 4.12 on average (Table 2). It is not possible to accurately state the reason for later development in Pelotas than in Canoinhas, since the sprouting stage was standardized and the growing season similar. In Pelotas, the total rainfall in the period was 680.80 $\mathrm{mm}$, the average daily temperature was $17.8^{\circ} \mathrm{C}$, and the average daily minimum temperature was $13.8^{\circ} \mathrm{C}$. These are higher values compared to Canoinhas $\left(558.20 \mathrm{~mm}, 16.7^{\circ} \mathrm{C}\right.$ and $7.2{ }^{\circ} \mathrm{C}$, respectively). On the other hand, the average daily maximum temperature $\left(22.68^{\circ} \mathrm{C}\right)$ and relative humidity (83.93\%) were lower than Canoinhas $\left(29.35^{\circ} \mathrm{C}\right.$ and $87.60 \%$, respectively).

\section{Brasilia experiment}

In Brasilia, phenotypic coefficients of variation were low, ranging from $9.87 \%$ for the height of the tallest stem to values close to $20 \%$ for leaf number, leaf mass, and mass and stem number (Table 3). The values of the rate between the coefficient of genotypic and phenotypic variation were higher than the unit for all traits, indicating a predominance of genotypic variation over phenotypic variation. Regarding the leaf mass, the two genotypes presented similar maximum values, but 'Asterix' was earlier than F18308-01, with maximum values already in the first harvest, at 38 DAP, but decreasing from this date.

The maximum leaf number was also similar for both genotypes, but also occurred earlier in 'Asterix' (46.77 DAP) than in F183-08-01 (71.05 DAP). The root mass plus stem mass and the stem number were higher for 'Asterix', which had practically twice the stems (6.82) compared to F183-08-01 (3.75). However, F183-08-01 presented higher stem height $(66.43 \mathrm{~cm})$ and higher leaf area index (3.19) than 'Asterix', which had the following values, $54.04 \mathrm{~cm}$ and $2.12 \mathrm{~m}^{2} / \mathrm{m}^{2}$, respectively. Regarding the tuber yield, both genotypes presented similar values to $80 \mathrm{DAP}$, and were still in full growth at this time (Table 3), but due to plant death in the plots by Ralstonia solanacearum did not have enough plants for subsequent harvests, but only for the final yield assessment.

Although 'Asterix' stood out for the early tuber development in Brasilia, the largest leaf area (leaf area index, leaf number and leaf mass) near the end of the vegetative cycle, when there was a greater tuber development, was presented by the clone F183-08-01 (Table 3), which may have been the factor responsible for the higher tuber yield of this clone at this site at 105 DAP 
Table 3: Regression equations for plant traits evaluated between 38 and 80 DAP after planting of three potato genotypes in Brasilia-DF, in the winter crop season of 2018

$\begin{array}{lll}\text { Leaf mass (g) Asterix } & \text { Root mass }+ \text { Stem mass (g) } \\ & & \text { A }\end{array}$

$\mathrm{y}=-3.5027 \mathrm{x}+462.61$ $y=-0.0057 x^{3}+0.9196 x^{2}-46.722 x+914.08$ $y=-0.0003 x^{3}+0.0474 x^{2}-2.5435 x+51.89$ $3 \mathrm{x}^{3}+0.0474 \mathrm{x}^{2}-2.543$
$\mathrm{R}^{2}=1 \mathrm{P}=<0.01$ $0,3764 x^{2}+22,027 x-355,91$ $\mathrm{R}^{2}=0.96 \mathrm{P}=0.03$ $\mathrm{R}^{2}=1 \mathrm{P}=0.05$

MP: 2.12 at 73.00 days $\mathrm{R}^{2}=1 \mathrm{P}=0.04$ MP: 329.50 at 38 days e 182.39 at 80 days MP: 197.52 at66.41 days MP: 2.12 at 73.00 days MP: 55,56 at 46,47 days

\section{Leaf mass (g)}

Root mass + Stem mass $(\mathrm{g})$ F183-08-01

$y=-0.1163 x^{2}+14.393 x-122.38 \quad y=-0.004 x^{2}+0.4054 x+145.19$

$R^{2}=0.86 P=0.05$

$\mathrm{R}^{2}=0.94 \mathrm{P}=0.05$

$\operatorname{LAI}\left(\mathbf{m}^{2} / \mathbf{m}^{2}\right)$

Leaf number

MP: 322.93 at 61.87 DAP

MP: 155.46 at 50.67DAP

$y=-0.0004 x^{3}+0.0692 x^{2}-3.7341 x+62.61 \quad y=-0.00008 x^{3}+0.0138 x^{2}-0.7494 x+67.777$

$\mathrm{R}^{2}=1 \mathrm{P}=<0.01$

$\mathrm{R}^{2}=1 \mathrm{P}=0.05$

Overall mean: 274.72

Overall mean: 152.31

MP: 3.19 at 72.28 DAP

MP: 55.51 at 71.05 DAP

$$
\text { CV: } 19.71
$$

$$
\text { CV: } 17.70
$$

CVg/CV: 7.22

Overall mean: 1.13

Overall mean: 49.34

CVg/CV: 4.93

Stem number

CV: 12.87

CV: 19.45

CVg/CV: 5.47

\begin{tabular}{|c|c|c|c|}
\hline \multicolumn{4}{|c|}{ Asterix } \\
\hline Tuber mass (g) & Stem number & Height of >stem $(\mathrm{cm})$ & - \\
\hline$y=21.524 x-650.34$ & $y=0.0005 x^{3}-0.0853 x^{2}+4.9643 x-87.58$ & $y=0.0638 x+48.939$ & - \\
\hline $\mathrm{R}^{2}=0.99 \mathrm{P}=0.05$ & $\mathrm{R}^{2}=1 \mathrm{P}=0.01$ & $\mathrm{R}^{2}=0.97 \mathrm{P}=0.05$ & \\
\hline MP: 1071.58 at 80 days & MP: 6.82 at 56.86 days & MP: 54.04 at 80 days & \\
\hline
\end{tabular}

CVg/CV: 5.52

MP: 1071.58 at 80 days

F183-08-01

\begin{tabular}{lcc}
\hline Tuber mass $(\mathbf{g})$ & Stem number & Height of $>$ stem $(\mathbf{c m})$ \\
\hline $\mathrm{y}=24.244 \mathrm{x}-881.98$ & $\mathrm{y}=-0.00009 \mathrm{x}^{3}+0.0164 \mathrm{x}^{2}-1.0085 \mathrm{x}+24.53$ & $\mathrm{y}=-0.0009 \mathrm{x}^{3}+0.1624 \mathrm{x}^{2}-9.0779 \mathrm{x}+$ \\
$\mathrm{R}^{2}=0.99 \mathrm{P}=0.05$ & $\mathrm{R}^{2}=1 \mathrm{P}=0.05$ & $\mathrm{R}^{2}=1 \mathrm{P}=0.05$ \\
$\mathrm{MP}: 1057.54$ at 80 DAP & $\mathrm{MP}: 3.50$ at $67.50 \mathrm{DAP}$ & MP: 66.43 at $76.14 \mathrm{DAP}$ \\
\hline Overall mean: 584.02 & Overall mean: 3.75 & Overall mean: 53.88 \\
$\mathrm{CV}: 14.44$ & $\mathrm{CV}: 20.75$ & $\mathrm{CV}: 9.87$ \\
$\mathrm{CVg} / \mathrm{CV}: 8.97$ & $\mathrm{CVg} / \mathrm{CV}: 5.06$ & $\mathrm{CVg} / \mathrm{CV}: 6.93$
\end{tabular}

Leaf mass (mass of compound leaves detached from stems of each plant), g; Root mass + stem mass (mass of roots plus mass of stems of each plant), g; IAF (foliar area index, obtained by the rate between the measurements of square foot area occupied by the leaves of each plant, by the plot area occupied by the plants), $\mathrm{m}^{2} / \mathrm{m}^{2} ;$ Leaf number (total number of leaves of each plant); Tuber mass (mass of tubers of each plant), g; Stem number (number of stems of each plant); Height > stem (height of the highest plant), $\mathrm{cm}^{2}$. $\mathrm{R}^{2}$ : regression determination coefficient; MP: maximum production obtained and correspondent period; $\mathrm{CV}$ : coefficient of variation; $\mathrm{CVg} / \mathrm{CV}$ : rate between the genotypic and phenotypic coefficient of variation. 
(Table 4). In Pelotas, this clone was also the most productive, while the clone F50-08-01 showed intermediate tuber yield, although higher than 'Asterix'. In Canoinhas, however, the clone F50-08-01 was more productive than the others (Table 4).

In a study by Fernandes et al. (2010), it was also found that 'Asterix' had a large stem number per plant. Considering a similar leaf number between genotypes, as occurred between 'Asterix' and clone F183-08-01 in the Brasilia experiment, the leaf distribution on a higher stem number may represent a reduction in self-shading (Fernandes et al., 2010). In addition, a higher stem number tends to correlate with a higher tuber number per plant; however, in general, also with a smaller average size of these tubers (Silva et al., 2018b).

Silva et al. (2018b) evaluated the same clones of this study, in an earlier generation, in order to assess their yield potential against in comparison with other advanced clones and two checks, including 'Asterix'. The authors reported mean values of $58.57,56.69$ and $52.81 \mathrm{~cm}$ for the height of the tallest stem at $60 \mathrm{DAP}$, and stem number of $4.34,6.27$ and 6.24 for F183-08-01, F50-08-01 and 'Asterix', respectively. The authors also reported that both clones presented higher marketable tuber yield than cultivar
'Asterix', with average values of 29.75, 28.71 and $15.66 \mathrm{t}$ $\mathrm{ha}^{-1}$, respectively. These values were very similar to those observed in the present study for Pelotas and for Canoinhas, to the clone F50-08-01; however, lower than those obtained in Brasilia, where clone F183-08-01 presented marketable yield of $48.24 \mathrm{t} \mathrm{ha}^{-1}$ in the present study and $41.07 \mathrm{t} \mathrm{ha}^{-1}$ observed by Silva et al. (2018a), confirming the high yield potential of these clones.

Regarding the average yield of marketable tubers produced by 'Asterix' (16.21 t ha $\mathrm{t}^{-1}$ ), it was is close to those reported by Silva et al. (2012) of $13.24 \mathrm{t} \mathrm{ha}^{-1}$, by Pinto et al. (2010) of $18.40 \mathrm{tha}^{-1}$, and by Silva et al. (2017) of $13.97 \mathrm{t} \mathrm{ha}^{-1}$.

Fernandes et al. (2010) evaluated the growth of cultivar Asterix from 20 to 97 DAP, and verified 6.3 stems per plant on average. The authors also observed that the number of stems did not increase with the advance in the crop cycle. In that work, the length of the tallest stem of 'Asterix' was close to $60 \mathrm{~cm}$ and did not increase from 55 DAP on. The values reported by Fernandes et al. (2010) are close to the values obtained in the present work for the cultivar Asterix, especially in the Brasilia experiment. Fernandes et al. (2010) found that 'Asterix' had a higher number of leaves earlier compared to other cultivars, with

Table 4: Means grouping for potato tuber yield traits, evaluated at 100 days after planting in Canoinhas-SC, at 105 days in PelotasRS, and at in Brasilia-DF, in 2018

\begin{tabular}{|c|c|c|c|c|c|}
\hline & $\begin{array}{c}\text { TTY } \\
\left(\mathbf{t} \text { ha }^{-1}\right)\end{array}$ & $\begin{array}{l}\text { MTY } \\
\left(\mathbf{t} \text { ha }^{-1}\right)\end{array}$ & $\begin{array}{c}\text { MTN } \\
(\text { no./1000 ha-1) }\end{array}$ & $\begin{array}{c}\text { AMTM } \\
(\mathbf{g})\end{array}$ & $\begin{array}{c}\text { PMTM } \\
(\%)\end{array}$ \\
\hline & \multicolumn{5}{|c|}{ Canoinhas-SC } \\
\hline Asterix & $21.63 \mathrm{a}$ & $16.35 \mathrm{~b}$ & $117.05 \mathrm{a}$ & $155.21 \mathrm{a}$ & $76.29 \mathrm{~b}$ \\
\hline F183-08-01 & $20.42 \mathrm{a}$ & $10.94 \mathrm{~b}$ & $110.69 \mathrm{a}$ & $98.96 \mathrm{a}$ & $53.17 \mathrm{c}$ \\
\hline F50-08-01 & $32.38 \mathrm{a}$ & $27.48 \mathrm{a}$ & $188.30 \mathrm{a}$ & $146.44 \mathrm{a}$ & $85.12 \mathrm{a}$ \\
\hline Overall mean & 24.81 & 18.26 & 138.68 & 133.54 & 71.52 \\
\hline $\mathrm{CV}$ & 21.59 & 19.70 & 32.77 & 31.40 & 4.55 \\
\hline \multirow[t]{2}{*}{$\mathrm{CVg} / \mathrm{CV}$} & 1.08 & 2.27 & 0.75 & 0.43 & 5.02 \\
\hline & \multicolumn{5}{|c|}{ Pelotas-RS } \\
\hline Asterix & $12.59 \mathrm{c}$ & $8.81 \mathrm{c}$ & $80.95 \mathrm{~b}$ & $108.30 \mathrm{c}$ & $86.82 \mathrm{a}$ \\
\hline F183-08-01 & $32.03 \mathrm{a}$ & $28.07 \mathrm{a}$ & $195.92 \mathrm{a}$ & $143.47 \mathrm{a}$ & $87.62 \mathrm{a}$ \\
\hline F50-08-01 & $24.41 \mathrm{~b}$ & $21.09 \mathrm{~b}$ & $169.31 \mathrm{a}$ & $124.56 \mathrm{~b}$ & $69.53 \mathrm{a}$ \\
\hline Overall mean & 23.01 & 19.32 & 148.73 & 125.44 & 81.32 \\
\hline $\mathrm{CV}$ & 11.45 & 7.08 & 9.44 & 4.20 & 11.42 \\
\hline \multirow[t]{2}{*}{$\mathrm{CVg} / \mathrm{CV}$} & 3.67 & 7.10 & 4.24 & 3.29 & 0.94 \\
\hline & \multicolumn{5}{|c|}{ Brasília-DF } \\
\hline Asterix & $35.44 \mathrm{~b}$ & $23.46 \mathrm{~b}$ & $121.37 \mathrm{~b}$ & $193.08 \mathrm{~b}$ & $65.99 \mathrm{~b}$ \\
\hline F183-08-01 & $58.60 \mathrm{a}$ & $48.24 \mathrm{a}$ & $178.91 \mathrm{a}$ & $269.83 \mathrm{a}$ & $82.35 \mathrm{a}$ \\
\hline Overall mean & 47.02 & 35.85 & 150.14 & 231.45 & 74.17 \\
\hline $\mathrm{CV}$ & 5.66 & 2.16 & 2.05 & 3.01 & 2.26 \\
\hline $\mathrm{CVg} / \mathrm{CV}$ & 6.12 & 22.61 & 13.20 & 7.76 & 6.89 \\
\hline
\end{tabular}

TTY: total tuber yield, $\mathrm{t} \mathrm{ha}^{-1}$; MTY: marketable tuber yield, t ha-1; MTN: marketable tuber number per ha ${ }^{-1} / 1000$; AMTM: average marketable tuber mass, g; PMTM: Percentage of marketable tuber mass; CV: coefficient of variation; CVg/CV: genotypic coefficient of variation / phenotypic coefficient of variation; Means followed by different letters in the column differed significantly by the Skott and Knott test or by the test at $5 \%$ probability of the error. 
Table 5: Phenotypic correlations between plant traits evaluated of three potato genotypes between 30 and 100 days after planting in Canoinhas-SC, upper diagonal; and between 34 and 105 days after planting in Pelotas-RS, lower diagonal, in spring crop season of 2018

\begin{tabular}{lccccccc}
\hline & $\begin{array}{c}\text { Leaf } \\
\text { mass }\end{array}$ & $\begin{array}{c}\text { Root } \\
\text { mass+ Stem }\end{array}$ & LAI & $\begin{array}{c}\text { Leaf } \\
\text { number }\end{array}$ & $\begin{array}{c}\text { Tuber } \\
\text { mass }\end{array}$ & $\begin{array}{c}\text { Stem } \\
\text { number }\end{array}$ & $\begin{array}{c}\text { Height of } \\
\text { >stem }\end{array}$ \\
\hline Leaf mass & & $0.70^{*}$ & $0.98^{*}$ & $0.97^{*}$ & -0.49 & 0.38 & 0.37 \\
Root mass + Stem & $0.86^{*}$ & & $0.62^{*}$ & $0.71^{*}$ & 0.12 & 0.24 & $0.77^{*}$ \\
LAI & $0.97^{*}$ & $0.89^{*}$ & & $0.96^{*}$ & -0.51 & 0.35 & 0.35 \\
Leaf number & $0.85^{*}$ & $0.94^{*}$ & $0.92^{*}$ & & -0.51 & 0.49 & 0.32 \\
Tuber mass & 0.50 & 0.43 & 0.53 & 0.53 & & -0.45 & $0.76^{*}$ \\
Stem number & -0.09 & -0.08 & -0.12 & -0.12 & -0.52 & & -0.33 \\
Height of > stem & $0.84^{*}$ & $0.81^{*}$ & $0.89^{*}$ & $0.87^{*}$ & $0.64^{*}$ & -0.28 & \\
\hline
\end{tabular}

*significant at $5 \%$ probability by the $t$ test with 54 observations.

Leaf mass (mass of compound leaves detached from the stems of each plant), g; Root mass + Stem (root mass plus stems mass of each plant), g; LAI (leaf area index, obtained by the ratio between the square meter measurements of the area occupied by the leaves of each plant, by the area of the plot occupied by the plants), $\mathrm{m}^{2} / \mathrm{m}^{2}$; Leaf number (total number of leaves of each plant); Tuber mass (mass of tubers of each plant), g: Tuber mass (mass of tubers of each plant), g; Stem number (number of stems of each plant); Height of > stem (height of the tallest stem of each plant), $\mathrm{cm}$.

approximately 70 leaves per plant at $50 \mathrm{DAP}$, stabilizing to close to 80 DAP and decreasing from this time on. The total tuber yield of this cultivar was close to $40 \mathrm{tha}^{-1}$ in that study. The time and leaf number reported by Fernandes et al. (2010) are similar to those observed in the present study in Canoinhas, and the total yield slightly higher than the present study in Brasilia.

The decrease in measurements and plant growth index (leaf mass, root mass plus stem mass, leaf area index, leaf number and height of the tallest stem), which occurred on average from 63.59 DAP for Brasilia, 72.25 DAP in Canoinhas, and a little later for Pelotas, at 87.82 DAP, and the corresponding increase in tuber mass, is due to a natural process of potato plants, in which photoassimilates produced in the aerial part are translocated to the tubers to be stored mainly as starch. This process begins at the early stage of tuber formation, and tends to accelerate with crop development, gradually decreasing at the end of the growth cycle and finishing with plant senescence (Fernandes et al., 2010).

Regarding the leaf area index, other studies have been done on evaluation of this trait in the cultivar Asterix, used as a check in this work, and found contrasting values, ranging from close to 1.00 (Zanon et al., 2013) to 3.21 and 4.44 (Cogo et al., 2006), while in the present study it ranged from 0.49 to 3.06. Higher leaf area values, within certain limits, may be related to higher interception of solar radiation and associated with higher plant growth and tuber production (Jadoski et al., 2012), but may vary for the same cultivar due to various factors, such as fertilization (Cogo et al., 2006) and irrigation management (Aguiar Netto et al., 2000). The best spatial distribution of the leaf area, which would provide better photosynthetic efficiency, may depend, for example, on stem number per plant (Fernandes etal., 2010).
To better understand the relationship between the traits measured in successive harvests, a simple correlation test was performed between the traits (Table 5).

For Brasilia, correlations were generally non-significant and, as they involved only two genotypes, were not discussed. In Canoinhas and Pelotas, significant correlations were observed between the traits leaf mass, leaf number, leaf area index and root mass plus stem mass, all of which were correlated with each other. Outstanding correlations, above $90 \%$, was between leaf area index and leaf number and leaf mass. There were also significant correlations, at both sites, of the height of the tallest stem with the root mass plus stem mass and with the tuber mass, indicating that plants with taller stems presented higher tuber yield. The height of the tallest stem was also positively correlated with leaf mass and leaf number and leaf area index, in both sites, but being significant for Pelotas. According to Silva et al. (2018b), traits related to the plant vegetative growth, such as stem number, stem size and plant vigor are related to the index of vegetative area available for photosynthesis. Some studies reported direct relationship of these traits with tuber yield, such as the positive relationship between plant height and tuber yield (Khayatnezhad et al., 2011; Arslan, 2007; Fekadu et al., 2013), and plant vigor with tuber yield (Silva et al., 2007; Pereira et al., 2017).

\section{CONCLUSIONS}

Clones F183-08-01 and F50-08-01 have high tuber yield potential, but have later plant development than the cultivar Asterix; therefore, management should be adapted to this trait.

Leaf mass, leaf number, leaf area index and root mass plus stem mass are correlated with each other; but, higher

Rev. Ceres, Viçosa, v. 67, n.3, p. 207-215, may/jun, 2020 
correlations exist between leaf area index and leaf number and leaf mass, indicating that the evaluation of one of these traits may be sufficient to characterize or quantify the leaf proportion of potato plants.

Significant correlations between the height of the tallest stem and root mass plus stem mass and tuber mass indicate that plants with taller stems, i.e., more vigorous plants, present higher tuber yield.

\section{ACKNOWLEDGEMENTS, FINANCIAL SUPPORT AND FULL DISCLOSURE}

The authors would like to thank Embrapa of the Brazilian government for the financial support for the research in this paper. We took the opportunity to inform that there was no conflict of interest.

\section{REFERENCES}

Aguiar Netto ADO, Rodrigues JD \& Pinho SZ (2000) Análise de crescimento na cultura da batata submetida a diferentes lâminas de irrigação. Pesquisa Agropecuária Brasileira, 35:901-907.

Arslan B (2007) Relationship among yield and some yield characters in potato (S. tuberosum L.). Journal of Biological Sciences, 7:973-976.

Busato C, Fontes PCR, Braun H \& Busato CCM (2010) Estimativa da área foliar da batateira, cultivar Atlantic, utilizando dimensões lineares. Revista Ciência Agronômica, 41:702-708.

Cogo CM, Andriolo JL, Bisognin DA, Godoi RDS, Bortolotto OC \& Barros GT (2006) Crescimento, produtividade e coloração dos chips de tubérculos de batata produzidos sob alta disponibilidade de potássio. Ciência Rural, 36:985-988.

Cruz CD (2013) Genes: a software package for analysis in experimental statistics and quantitative genetics. Acta Scientiarum Agronomy, 35:271-276.

Cruz CD, Regazzi AJ \& Carneiro PCS (2014) Modelos biométricos aplicados ao melhoramento genético. $3^{\mathrm{a}} \mathrm{ed}$. Viçosa, UFV. $668 \mathrm{p}$.

Escalante FB, Fernández JM, López A, Parga VM, Murillo M \& Carvajal A (2016) Growth analysis in seven potato varieties (Solanum tuberosum L.). Agronomía Mesoamericana 11:145149

Fekadu A, Petros Y \& Zelleke H (2013) Genetic variability and association between agronomic characters in some potato (Solanum tuberosum L.) genotypes in SNNPRS, Ethiopia. International Journal of Biodiversity and Conservation, 5:523528 .

Fernandes AM, Soratto RP \& Beatrice LSR (2010) Extração e exportação de nutrientes em cultivares de batata: I macronutrientes. Revista Brasileira de Ciência do Solo, 35:20392056.

IBGE - Instituto Brasileiro de Geografia e Estatística (2018) Produção Agrícola Municipal: informações sobre culturas temporárias. Avaliable at: <http://www.sidra.ibge.gov.br/bda/pesquisas/ pam/default.asp.>. Acessed on: November $4^{\text {th }}, 2019$.

Jadoski SO, Lopes CE, Furlan MM, Suchoronczek A, Romão SL \& Denega S (2012) Método de determinação da área foliar da cultivar de batata Agata a partir de dimensões lineares. Semina: Ciências Agrárias, 33:2545-2554.
Khayatnezhad MR, Shahriari BR \& Gholamin RG (2011) Correlation and path analysis between yield and yield components in potato (Solanum tuberosum L.). Middle-East Journal of Scientific Research, 7:17-21.

Lima JF, Peixoto CP \& Silva Ledo CA (2007) Índices fisiológicos e crescimento inicial de mamoeiro (Carica papaya L.) em casa de vegetação. Ciência e Agrotecnologia, 31:1358-1363.

Moreira CM, Pinto CABP, Ribeiro GHMR, Carneiro OLG \& Guedes ML (2015) Clones de batata tolerantes ao calor para diferentes segmentos de mercado. Amazonian Journal of Agricultural and Environmental Sciences, 58:138-145.

Pereira AS, Silva GO, Carvalho ADF \& Ponijaleki RS (2017) Performance of advanced potato clones: plant vigor, tuber yield and specific gravity. Horticultura Brasileira, 35:440-444.

Pinto CABP, Teixeira AL, Neder DG, Araújo RR, Soares ARO, Ribeiro GHMR \& Lepre A L (2010) Potencial de clones elite de batata como novas cultivares para Minas Gerais. Horticultura Brasileira, 28:399-405.

Silva GO, Pereira AS, Souza VQ, Carvalho FIF \& Neto RF (2007) Correlações entre caracteres de aparência e rendimento e análise de trilha para aparência de batata. Bragantia, 66:381-388.

Silva GO, Castro CM, Terres LR, Rohr A, Suinaga FA \& Pereira AS (2012) Desempenho agronômico de clones elite de batata. Horticultura Brasileira, 30:557-560.

Silva GO, Carvalho ADF, Pereira AS, Ragassi F \& Azevedo FQ (2017) Desempenho de clones avançados de batata para rendimento de tubérculos em quatro ambientes. Revista Agro@mbiente, 11:323-330.

Silva GO, Pereira AS, Azevedo FQ, Carvalho ADF \& Pinheiro JB (2018) Selection of potato clones for tuber yield, vine maturity and frying quality. Horticultura Brasileira, 36:276-281.

Silva GO, Pereira AS, Carvalho ADF \& Azevedo FQ (2018b) Seleção genotípica de clones de batata para rendimento de tubérculos, aspecto vegetativo e qualidade de fritura. Revista Brasileira de Ciências Agrárias, 13:01-10.

Virmond EP, Kawakami J, Souza-Dias JAC (2017) Seed-potato production through sprouts and field multiplication and cultivar performance in organic system. Horticultura Brasileira, $35: 335-342$.

Zanon AJ, Streck NA, Kräulich B, Silva MR \& Bisognin DA (2013) Desenvolvimento das plantas e produtividade de tubérculos de batata em clima subtropical. Revista Ciência Agronômica, 44:858-868. 